\title{
COMPARISON OF MEASURED AND CALCULATED CONTROL ROD WORTH OF THE RSG-GAS WORKING CORE CONFIGURATION
}

\section{PERBANDINGAN HASIL PERHITUNGAN DAN PENGUKURAN NILAI REAKTIVITAS BATANG KENDALI KONFIGURASI TERAS BARU RSG-GAS}

\author{
T. Surbakti1), W.Luthfi1), Purwadi2), D. Hartanto3) \\ ${ }^{1}$ Center for Nuclear Reactor Safety and Technology, National Nuclear Energy Agency (BATAN) Kawasan Puspiptek \\ Gd 80 Serpong, Tangerang Selatan, Banten 15310, Indonesia \\ ${ }^{2}$ Center of Multipurpose Reactor (PRSG), National Nuclear Energy Agency (BATAN) \\ Kawasan Puspiptek Gd 31 Serpong, Tangerang Selatan, Banten 15310, Indonesia \\ 3Department of Mechanical and Nuclear Engineering, University of Sharjah, P.O. BOX 27272, Sharjah, United Arab \\ Emirates. \\ E-mail:tukiran@batan.go.id
}

Received 30 June 2020, Received in revised form 21 December 2020, Accepted 28 December 2020

\begin{abstract}
COMPARISON OF MEASURED AND CALCULATED CONTROL ROD WORTH OF THE RSG-GAS WORKING CORE CONFIGURATION. The reactivity worth of the RSG-GAS core control rod is a very important reactor parameter and is closely related to operational safety. The reactivity worth of the RSG-GAS core control rod must be determined during the beginning of cycle $(\mathrm{BOC})$ of the new core configuration. Measurement of control rod reactivity by various methods has been carried out in the RSG-GAS core. The measurement used today is paired one by one compensation. The reactivity worth of each control rod has been proven by calculations using the Batan-3DIFF diffusion codes and the results are very satisfying. The results of measuring the reactivity of control rods have never been compared with the results of calculations using the Monte Carlo method. In this work, the total reactivity worth of the control rods of the G.A Siwabessy Multipurpose Reactor (RSG-GAS) core measurement results will be verified with the calculation results for the new core configuration. The calculations were carried out by diffusion and Monte Carlo methods using computer codes Batan-3DIFF and MCNP5. The total reactivity values of the control rods were obtained $17.54 \$, 17.03 \$$ and $17.87 \$$ by measurement, MCNP5 and Batan-3DIFF calculations, respectively. The relative difference between the measurement value and the calculated control rod reactivity value is approximately $3.0 \%$, which indicates a good fit between the measurement and calculation methods.
\end{abstract}

Keywords: MCNP5, RSG-GAS reactor , Control rod, Batan-3DIFF

\section{ABSTRAK}

PERBANDINGAN HASIL PERHITUNGAN DAN EKSPERIMEN NILAI REAKTIVITAS BATANG KENDALI KONFIGURASI TERAS BARU RSG-GAS. Nilai reaktivitas batang kendali teras RSG-GAS adalah suatu parameter reaktor yang sangat penting dan berhubungan erat dengan keselamatan operasi. Nilai reaktivitas batang kendali teras RSG-GAS harus ditentukan saat pembentukan awal konfigurasi teras baru (BOC). Pengukuran reaktivitas batang kendali dengan berbagai macam metode telah dilakukan di teras RSG-GAS. Pengukuran yang digunakan saat ini adalah dengan kompensasi berpasangan satu satu. Nilai reaktivitas setiap batang kendali ini sudah dibuktikan dengan perhitungan menggunakan program difusi Batan-3DIFF dan hasilnya sangat memuaskan. Hasil pengukuran reaktivitas batang kendali belum pernah dibandingkan dengan hasil perhitungan dengan metode Monte Carlo. Dalam penelitian ini, nilai total reaktivitas batang kendali teras Reaktor Serba Guna G.A Siwabessy (RSG-GAS) hasil pengukuran akan diverifikasi dengan hasil perhitungan untuk konfigurasi teras baru. Perhitungan dilakukan dengan metode difusi dan Monte Carlo menggunakan program komputer Batan-3DIFF dan MCNP5. Nilai total reaktivitas batang kendali diperoleh 17,54 \$, 17,03\$ dan 17,87\$ masing-masing dengan pengukuran, perhitungan MCNP5 dan Batan-3DIFF . Perbedaan relatif antara nilai pengukuran dan perhitungan nilai reaktivitas batang kendali adalah sekitar 3,0\%, yang menunjukkan kesesuaian yang baik antara metode pengukuran dan perhitungan.

Kata kunci: MCNP5, reaktor RSG-GAS, Batang kendali, Batan-3DIFF 
Jurnal Iptek Nuklir Ganendra

Ganendra Journal of Nuclear Science and Technology

Vol. 24 No. 1, January - 2021: 11-20

\section{INTRODUCTION}

Co ontrol rod reactivity worth is crucial for the RSG-GAS nuclear reactor after 30 years of operation. One of the main purposes of control rods is to shut down the reactor in case of an emergency. Control rods are also used for providing positive reactivity into the core during RSG-GAS startup in the case of xenon peaking at the postshutdown condition $[1,2]$. Thus, determining the negative reactivity of the total control rod becomes important. The control rod in the RSG-GAS reactor core was designed to cover the excess reactivity. This is why a control absorber is placed in the center part of the core which has a high neutron flux. Control rod worth can also be measured experimentally, for instance, using the inserted compensation method. This research focuses on the estimation of the control rod worth for the working core of the RSG-GAS reactor. However, control rod worth calculation using a Monte Carlo method has not been conducted. In this paper, the deterministic and Monte Carlo calculation results for control rod reactivity of the RSG-GAS working core is presented and compared with the measurement data. The purpose of this research is to obtain the integral and differential reactivity of the RSG-GAS control rod of the working core. This result is used as a verification and validation data and also for periodic safety review (PSR). The MCNP5 code [3,4] was used in the entire calculations. In this research, the nuclear data libraries ENDFVII.1 [5] is used in code. The Monte Carlo method has been selected since it is the most accurate method for the integral and differential control rod reactivity calculations. The working core was chosen due to, the completeness of the experimental data and geometry, dimension, and composition of the core details. Many researchers have calculated the control rod reactivity worth using computer code [6-9]. However, in this work, the Monte Carlo and diffusion methods are implemented to look at the impact of neutron cross-section data grouping in the simulation. In the early application of Monte Carlo code for criticality calculations, the group approximation with many energy groups was commonly used since the computer memory and computational capacity were then limited. With the rapid development of computer technology, the limitation can be relaxed significantly. The most advanced Monte Carlo codes, such as MCNP5 that was used in the present work, use the continuous energy cross-section data which removes the approximation applied in the neutron energy variable. On top of that, to save computational time, the code has been vectorized by taking advantage of the parallel processing technology presently available. The measurement data will be compared to the calculation result using the deterministic method (Batan-3DIFF). BATAN's standard neutron diffusion code, Batan-3DIFF [10] code, has been developed for neutronic design and safety analysis review, especially the design and analysis of research reactors. Those codes solve the threedimensional multigroup neutron diffusion problems.

\section{METHODOLOGY}

The core configuration as shown in Figure 1 consists of 40 fuels and 8 control rods. Figure 2 shows a fuel in 2 dimensions and Figure 3 shows the control element. For performing reactivity control rod calculation of the RSG-GAS, there are 2 steps used for reactor simulation. The first step is the cell calculation that simulates fuel assemblies in the reactor core with WIMSD-5B code. In this step, the WIMSD-5B code is used to calculate the macroscopic cross-section of the core material, especially the silicide fuel assembly, the beryllium block reflector, the beryllium element reflector, and the coolant, then create a library for silicide fuels. Furthermore, in the second step, the core calculation is carried out by adding the RSG-GAS core geometry data for the calculation of the neutronic parameters. The goal is to obtain the macroscopic constant needed for core calculations. The WIMSD (Winfrith Improved Multi-group Scheme) program package is a cell calculation [11]. This program package was developed initially by AEE Winfrith. Cell units that can be handled by WIMSD consist of 3 or 4 regions [12], namely fuel (1), can or cladding (2), coolant (3), and moderator (4) which are represented in a slab. Figure 4 illustrates the fuel cell model. 


\begin{tabular}{|c|c|c|c|c|c|c|c|c|c|}
\hline JF 02 & JF 15 & $\begin{array}{c}\text { JF } \\
51+85\end{array}$ & JF 14 & RS 1 & RS 2 & RS 3 & RS 4 & RS 5 & JF 01 \\
\hline JF 05 & $\begin{array}{c}\text { JF } \\
52+84\end{array}$ & JF 17 & \begin{tabular}{|c|} 
JF \\
$37+73$
\end{tabular} & JF 32 & JF 34 & JF 36 & JF 37 & JF 11 & JF \\
\hline $\begin{array}{c}\text { JF } \\
60+83\end{array}$ & JF 04 & JF 19 & $\mathrm{JF} 40$ & $\begin{array}{c}\text { FE RI } \\
574\end{array}$ & $\begin{array}{c}\text { FE RI } \\
560\end{array}$ & $\begin{array}{c}\text { FE RI } \\
551\end{array}$ & $\begin{array}{c}\text { FE RI } \\
573\end{array}$ & JF 06 & $\mathrm{JF} 03$ \\
\hline JF 08 & JF 24 & $\begin{array}{c}\text { FE RI } \\
571\end{array}$ & $\begin{array}{c}\text { FE RI } \\
542\end{array}$ & $\begin{array}{c}\text { FE RI } \\
536\end{array}$ & $\begin{array}{c}\text { JD } \\
108\end{array}$ & \begin{tabular}{|l|} 
JDA07+09 \\
$R I-561$ \\
\end{tabular} & $\begin{array}{c}\text { FE RI } \\
559\end{array}$ & $\begin{array}{c}\text { FE RI } \\
553\end{array}$ & \begin{tabular}{|c} 
FE RI \\
567
\end{tabular} \\
\hline JF 13 & $\mathrm{JF} 23$ & $\begin{array}{c}\text { FE RI } \\
549\end{array}$ & $\begin{array}{c}\text { FE RI } \\
541\end{array}$ & \begin{tabular}{|l|} 
JDA04+13 \\
RI - 564 \\
\end{tabular} & $\begin{array}{c}\text { FE RI } \\
544\end{array}$ & $\begin{array}{c}\text { FE RI } \\
554\end{array}$ & \begin{tabular}{|l|} 
JDA05+16 \\
RI - 562 \\
\end{tabular} & $\begin{array}{c}\text { FE RI } \\
530\end{array}$ & $\begin{array}{c}\text { FE RI } \\
557\end{array}$ \\
\hline JF 20 & JF 21 & $\begin{array}{c}\text { FE RI } \\
552\end{array}$ & $\begin{array}{l}\mathrm{JDA02+12} \\
\mathrm{RI} \text { - } 539\end{array}$ & $\begin{array}{c}\mathrm{FERI} \\
531\end{array}$ & $\begin{array}{c}\text { JD } \\
103\end{array}$ & $\begin{array}{l}\text { JD } \\
106\end{array}$ & $\begin{array}{c}\text { FE RI } \\
546\end{array}$ & $\begin{array}{l}\text { JD } \\
104\end{array}$ & \begin{tabular}{|c} 
FE RI \\
548
\end{tabular} \\
\hline \multicolumn{2}{|c|}{$P R T F$} & $\begin{array}{c}\text { FE RI } \\
550\end{array}$ & $\begin{array}{c}\text { JD } \\
101\end{array}$ & $\begin{array}{c}\text { FE RI } \\
545\end{array}$ & $\begin{array}{c}\text { JD } \\
107\end{array}$ & $\begin{array}{c}\text { JD } \\
105\end{array}$ & $\begin{array}{c}\text { FE RI } \\
533\end{array}$ & \begin{tabular}{|l|} 
JDA08+14 \\
$R I-538$ \\
\end{tabular} & $\begin{array}{c}\text { FE RI } \\
555\end{array}$ \\
\hline JF 30 & JF 22 & $\begin{array}{c}\text { FE RI } \\
568\end{array}$ & $\begin{array}{c}\text { FE RI } \\
532\end{array}$ & \begin{tabular}{|l|}
$\mathrm{JDA} A 03+10$ \\
$\mathrm{RI}-563$ \\
\end{tabular} & $\begin{array}{c}\text { FE RI } \\
556\end{array}$ & $\begin{array}{c}\text { FE RI } \\
529\end{array}$ & \begin{tabular}{|l|} 
JDA $066+11$ \\
RI - 583 \\
\end{tabular} & $\begin{array}{c}\text { FE RI } \\
528\end{array}$ & \begin{tabular}{|c|} 
FE RI \\
535
\end{tabular} \\
\hline JF 29 & $\begin{array}{l}\text { JF } \\
58+72\end{array}$ & $\begin{array}{c}\text { FE RI } \\
575\end{array}$ & \begin{tabular}{|c|} 
FE RI \\
565
\end{tabular} & $\begin{array}{c}\text { FE RI } \\
566\end{array}$ & \begin{tabular}{|l|} 
JDA01+15 \\
RI - 540 \\
\end{tabular} & \begin{tabular}{|l|l}
5 & JD \\
102
\end{tabular} & $\begin{array}{c}\text { FE RI } \\
534\end{array}$ & $\begin{array}{c}\text { FE RI } \\
543\end{array}$ & $\begin{array}{c}\text { FE RI } \\
572\end{array}$ \\
\hline $\begin{array}{c}\mathrm{JF} \\
59+71\end{array}$ & JF 28 & JF 26 & JF 16 & $\begin{array}{c}\text { FE RI } \\
570\end{array}$ & $\begin{array}{c}\text { FE RI } \\
558\end{array}$ & $\begin{array}{c}\text { FE RI } \\
547\end{array}$ & $\begin{array}{c}\text { FE RI } \\
569\end{array}$ & $\begin{array}{c}\mathrm{JF} \\
54+\mathrm{NS}\end{array}$ & JF 10 \\
\hline & $\mathbf{J}$ & 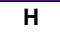 & G & $\mathbf{r}$ & E & D & C & B & A \\
\hline
\end{tabular}

$\mathrm{FE}=$ Fuel Element; JDA $=$ Control Element; JF = Beryllium; JD = Irradiation position

Figure 1. RSG-GAS core configuration [13].

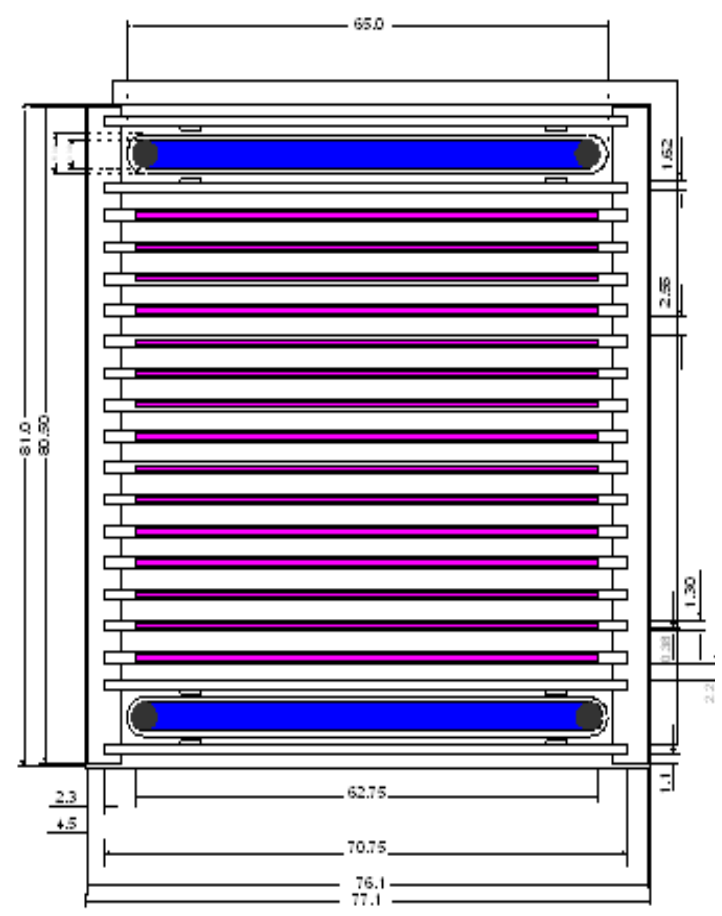

Figure 2. The fuel element of the RSG-GAS core [13].

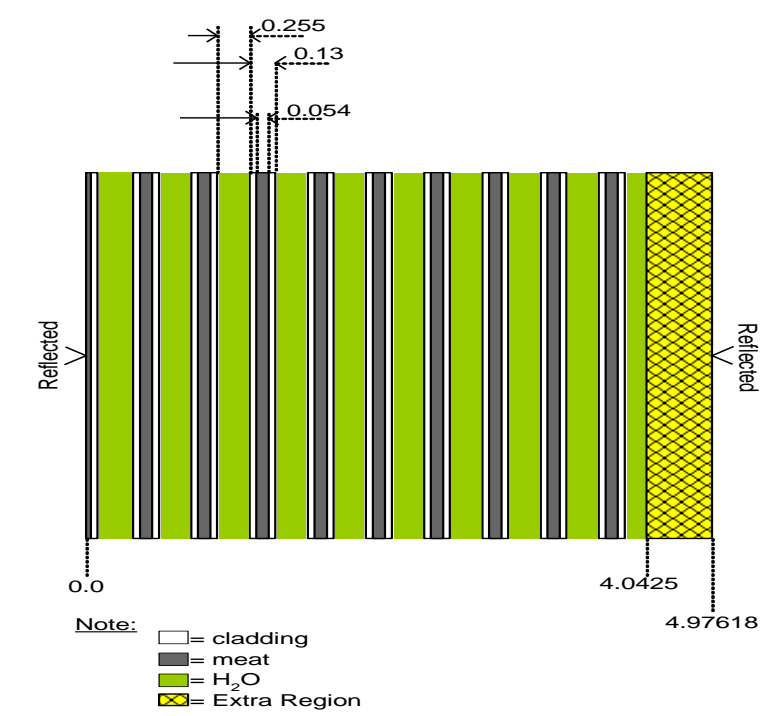

Figure 4. Fuel cell model [15].

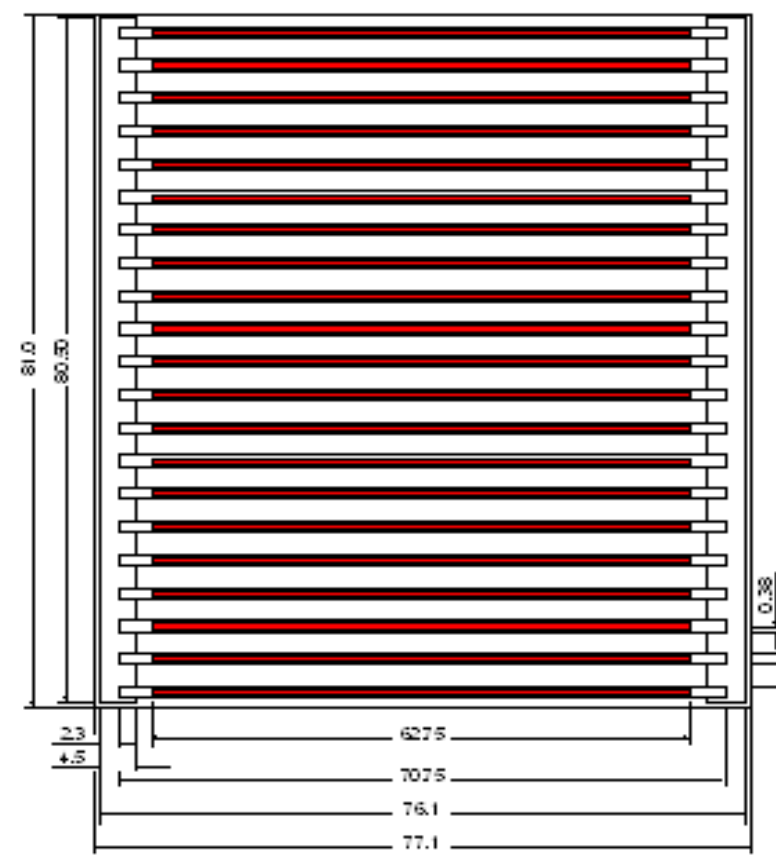

Figure 3. Control rod fuel element of the RSG-GAS core [14].

\section{WIMSD-5B code Cell Calculation.}

The WIMSD-5B code performs cell calculations for reactor core materials applicable to various types of reactors including thermal and fast reactors. The result of this code provides reaction rates and cross-section for 
Jurnal Iptek Nuklir Ganendra

Ganendra Journal of Nuclear Science and Technology

Vol. 24 No. 1, January - 2021: 11-20

the lattice and eigenvalues for cases where a simple buckling mode is applied. Alternatively, average cell constants and corrected for leakage are required for using in the overall reactor calculation. The structure of the neutron energy in this case is $10 \mathrm{MeV}, 0.821 \mathrm{MeV}, 5.531 \mathrm{keV}, 0.625 \mathrm{eV}$ and $1 \times 10^{-5} \mathrm{eV}[16,17]$. The unit cell used in determining the macroscopic cross-section depends on the composition and width of the cells used. Material and spectrum data are adjusted to four regions, namely fuel, cladding, coolant and extra regions that are available in the WIMSD-5B program package. The calculation of the macroscopic cross section greatly determines the accuracy of the core calculation to determine the neutronic parameter. The WIMDSD-5B program package uses this 4-area approach to obtain highly accurate results. The results of cell calculations produced by the WIMSD-5B program include: neutron flux, k-inf, diffusion coefficient, absorption cross-section, nu sigma fission in 4 neutron energy groups.

The results of the WIMSD-5B calculation in the form of macroscopic constants are used for core calculation to obtain neutronic parameters with core conditions. Table 1 is the material and the size of the fuel and the control rods used in the calculation of WIMSD-5B and Batan-FUEL.

Table 1. Design data for RSG-GAS core [18].

\begin{tabular}{ll}
\hline Parameter & Values \\
\hline Core grid dimension $(\mathrm{cm})$ & $7.71 \times 81 \times 60$ \\
Fuel plate thickness $(\mathrm{cm})$ & 0.13 \\
The channel width of Coolant $(\mathrm{cm})$ & 0.255 \\
Plates for fuel element number & 21 \\
Plates for control element number & 15 \\
Material of cladding & AlMg2 \\
Material of edge plate & AlMg1 \\
Fuel cladding thickness $(\mathrm{cm})$ & 0.038 \\
Dimension of active zone, $(\mathrm{cm})$ & $0.054 \times 6.275 \times 60$ \\
Material of fuel & $\mathrm{U}_{3} \mathrm{Si} 2-\mathrm{Al}$ \\
Uranium fuel loading $(\mathrm{gram})$ & 250 \\
Material of absorber & $\mathrm{Ag}-\mathrm{In}-\mathrm{Cd}$ \\
Absorber thickness $(\mathrm{cm})$ & 0.338 \\
Material of absorber cladding & $\mathrm{SS}-321$ \\
Absorber cladding thickness $(\mathrm{cm})$ & 0.085 \\
\hline
\end{tabular}

Then, the second step is to calculate the control rod reactivity as a core parameter using the diffusion and Monte Carlo methods with the Batan-3DIFF and MCNP5 codes.

\section{Diffusion Calculation.}

Core calculations are performed to obtain control rod reactivity worth with the Batan-FUEL program which consists of several programs such as Batan-2DIFF and Batan-3DIFF and Batan-Equil. The flow diagram of the neutronic parameter calculation can be seen in Figure 5. The Batan-FUEL code is used for calculating the criticality search of an equilibrium core without simulating the transition cores [19]. Therefore, those capabilities strongly depend on the cell calculation. The calculation results will be compared to the measurement data.

\section{Monte Carlo Calculation}

The active part of fuel assembly $(7.71 \mathrm{~cm} \times 8.1 \mathrm{~cm} \times 60 \mathrm{~cm})$ and control fuel elements were modeled as precise geometries and dimensions. However, the highest part and end-fitting of the elements were modeled in an approximate model since their geometries are very complicated. The core materials were homogenized with water by volume weighting. Accurate modeling was carried out for the silicide fuel element assemblies, beryllium reflector elements, beryllium block elements, and the position of the RSG-GAS core irradiations. The geometry of the RSGGAS core is needed in a very complex 3-dimensional form, so that simplification is needed in the model. Primarily, the core grid and the lower supports are modeled approach, as are the top or end of the silicide fuel element assembly. This simplification does not affect the value of the accuracy of the Monte Carlo calculation because it is 
carried out on the part of the core that does not contain uranium or is often called the active core. AglnCd is a control rod absorber material which is also modeled with accurate geometry and dimensions. A layer of cooling water $60 \mathrm{~cm}$ above the core surface shall be modeled in the calculations to provide sufficient space for the absorbent material when the control rod is fully pulled up. The vacuum boundary conditions apply to the periphery of the RAG-GAS reactor system. Calculations using the MCNP5 program in this work were carried out using the ENDFVII.1 library with a material temperature of $300 \mathrm{~K}$. The critical effective multiplication factor (K-eff) value is corrected when the core temperature is not $300 \mathrm{~K}$. The total number of simulated particles in all cases of this calculation is 600,000 . The calculation results from the MCNP5 program will be compared with the measurement results. Based on the experience of calculating control rod values using deterministic and probalistic codes (Monte Carlo) [20] which cannot be modeled is the decay of control rod reactivity values during use in the RSG-GAS core. Three parameters are analyzed: the calculated $k_{\text {eff }}$ as a function of control rod withdrawal, the S-shape of the integral control rod, and differential reactivity of the control rod.

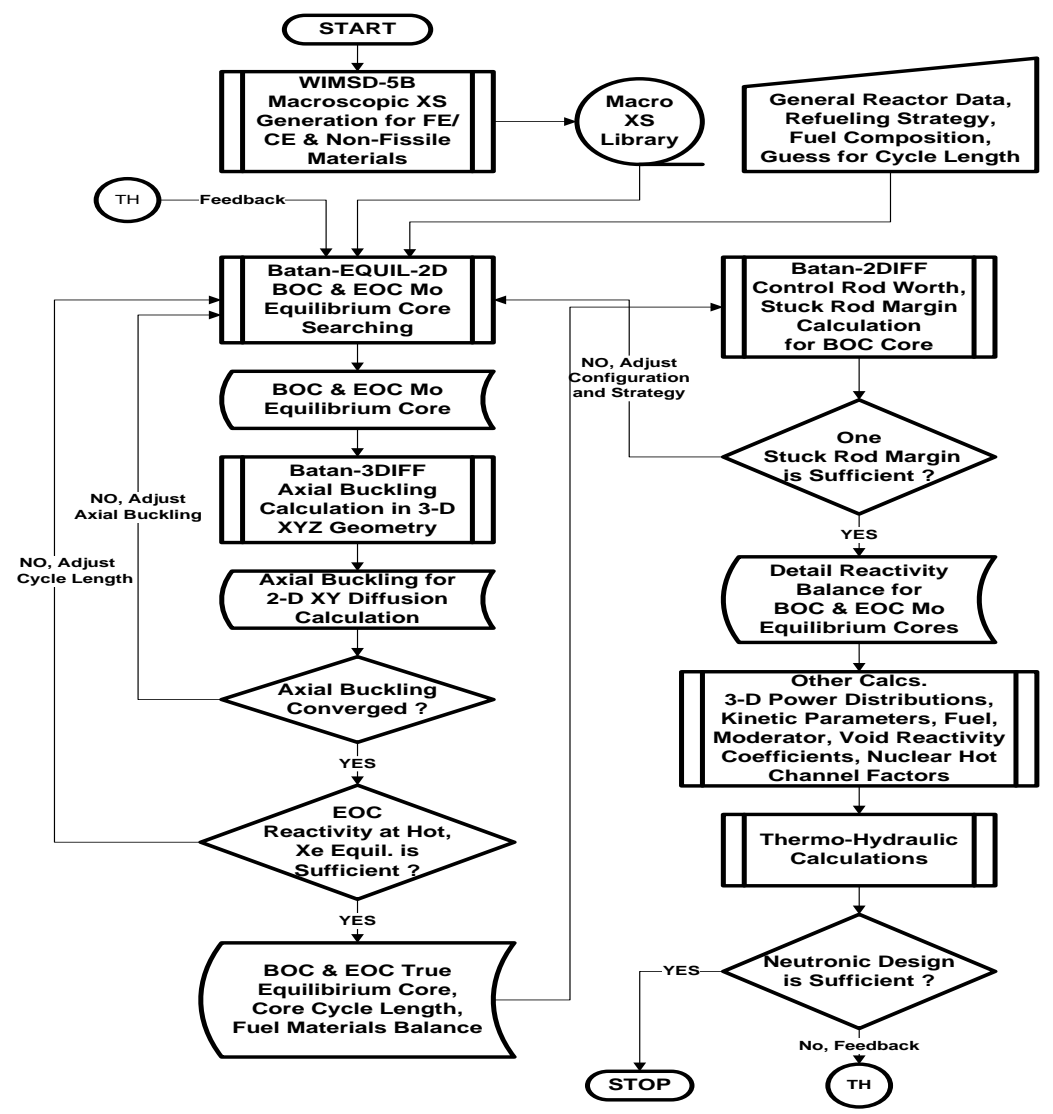

Figure 5. Flowchart of core calculation for Batan-FUEL code (20].

\section{RESULT AND DISCUSSION}

There are 8 control rods in the working core of RSG-GAS reactor at positions of E-9, G-6, F-8, F-5, C-5, C8, B-7, and D-8. The calculation result of $k_{\text {eff }}$ for RSG-GAS core is shown in Table 2. According to MCNP5 and Batan-3DIFF calculation results, the $k_{\text {eff }}$ values are 1.092 and 1.102 for all control rods fully up, 0.956 , and 0.958 for all control rods fully down. The difference in the results of this calculation is only $1 \%$. 
Table 2. The calculation result of $k_{\text {eff }}$ for RSG-GAS core.

\begin{tabular}{ccc}
\hline \multirow{2}{*}{ Control rod position } & \multicolumn{2}{c}{$k_{\text {eff }}$} \\
\cline { 2 - 3 } & MCNP5 & Batan-3DIFF \\
\hline All-up & 1.092 & 1.102 \\
All-down & 0.956 & 0.958 \\
\hline
\end{tabular}

Table 3 shows the comparison between measurement data and Batan3-DIFF calculation results for RSGGAS working core that using the ENDFVII.1 data file. The differences between calculated and measurement results for total control rod worth and therefore, the excess reactivity is $4.27 \%$ and $4.88 \%$, respectively. Table 3 also shows a comparison between Batan-3DIFF and calculation results for several parameters such us shut-down margin reactivity and stuck rod condition of RSG-GAS working core occurred during control rod calibration. Those parameters are also very related to the safety of the RSG-GAS reactor operation. The calculation result showed good agreement with the measurement result. The results of calculation and measurement no safety limits are exceeded.

Table 3. Control rod reactivity worth of the RSG-GAS reactor.

\begin{tabular}{llll}
\hline Control rod positions & $\begin{array}{c}\text { Calculation } \\
(\%)\end{array}$ & $\begin{array}{c}\text { Experiment } \\
(\%)\end{array}$ & $\begin{array}{c}\text { Deviation } \\
(\%)\end{array}$ \\
\hline JDA 01 + 15 / E-9 & -1.78 & -1.58 & 12.67 \\
JDA 02 + 12 / G-6 & -1.48 & -1.67 & 11.36 \\
JDA 03 + 10 / F-8 & -1.89 & -1.81 & 4.26 \\
JDA 04 + 13 / F-5 & -1.68 & -1.82 & 7.51 \\
JDA 05 + 16 / C-5 & -1.77 & -1.89 & 6.07 \\
JDA 06 + 11 / C-8 & -1.69 & -1.44 & 17.48 \\
JDA 07 + 09 /D-4 & -1.67 & -1.89 & 11.99 \\
JDA 08 + 14 / B-7 & -1.48 & -1.31 & 12.75 \\
Excess reactivity & 7.65 & 7.29 & 4.88 \\
Total control rod & -13.87 & -13.42 & 4.27 \\
reactivity & & & \\
Shutdown margin & -6.23 & -6.12 & 1.79 \\
reactivity & & & \\
Stuck rod condition & -4.38 & -4.23 & 2.58 \\
The largest control rod & -1.89 & -1.89 & 0.11 \\
reactivity & & & \\
\hline
\end{tabular}

Figure. 6 shows that the value of $k_{\text {eff }}$ as a function of control rod withdrawal by MCNP5 and Batan-3DIFF. The critical reactor $\left(k_{\text {eff }}=1\right)$ is achieved when all control rods are withdrawn by a height of $21.7 \mathrm{~cm}$ and $21.0 \mathrm{~cm}$, predicted by MCNP5 and Batan-3DIFF codes, respectively. Meanwhile, the measurement result is $22.7 \mathrm{~cm}$. In this regard, the MCNP5 calculation is closer to the measurement results.

The S-shape curve of control rods or the integral control rod worth can be seen in Figure. 7. It can be clearly observed from Figure. 7 that the control rod absorbs the most neutrons in the middle as expected in a typical nuclear reactor core so the peak value of differential reactivity of the control rod is located in the middle of the core. The function of the control rod is to control fission reactions in the reactor core so that it can operate properly and safely. The value of the control rod must be able to cover the core excess reactivity value. 


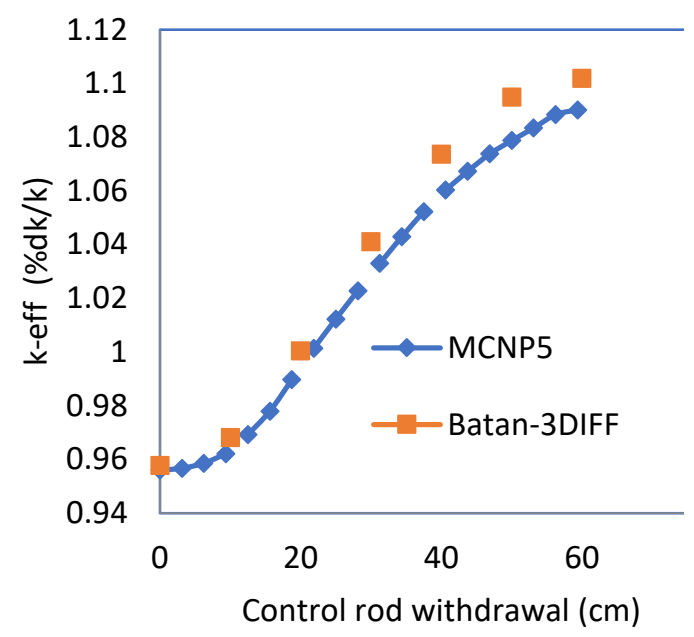

Figure 6. Keff values as a function of control rod withdrawal.

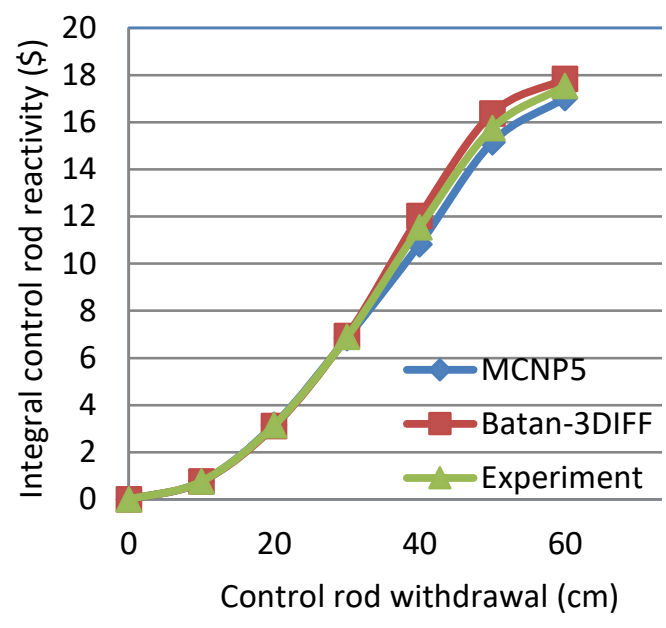

Figure 7. Integral control rod reactivity.

The $k_{\text {eff }}$ calculations for the MCNP5 curve were performed by using the previously described model of the RSG-GAS working core. There is a close agreement between the integral reactivity of control rod from the MCNP5, Batan-3DIFF calculated result, and the measurement result. Table 4 shows that the difference between measurement data and the computational results (Batan-3DIFF) is $1.9 \%$. From the comparison of the MCNP5 result of the measurement data, the difference is $3.0 \%$. It meets the criteria for the analysis of the integral control rod worth for RSG-GAS working core. The results show that the agreement between the calculation and the measurement in control rod reactivity worth is satisfactory. The S-shape of the measured integral control rod worth obtained from calculations and measurement data does not vary significantly. Also, it can be seen in Figure. 7 that the difference between the different curves is in their top part only. For the control rod at positions $20-40 \mathrm{~cm}$, the curves in the middle of this range are very sensitive to the reactivity because in that area the neutron flux in the RSG-GAS core is the highest and the S-shape of the curves there is no difference. For the lowest and highest parts of control rod are less sensitive because of those positions the neutron flux in the RSG-GAS core is lower. Therefore, it can be concluded that the calculation results are reliable for the control rod reactivity worth of the working core of RSG-GAS for verification and validation of data and model.

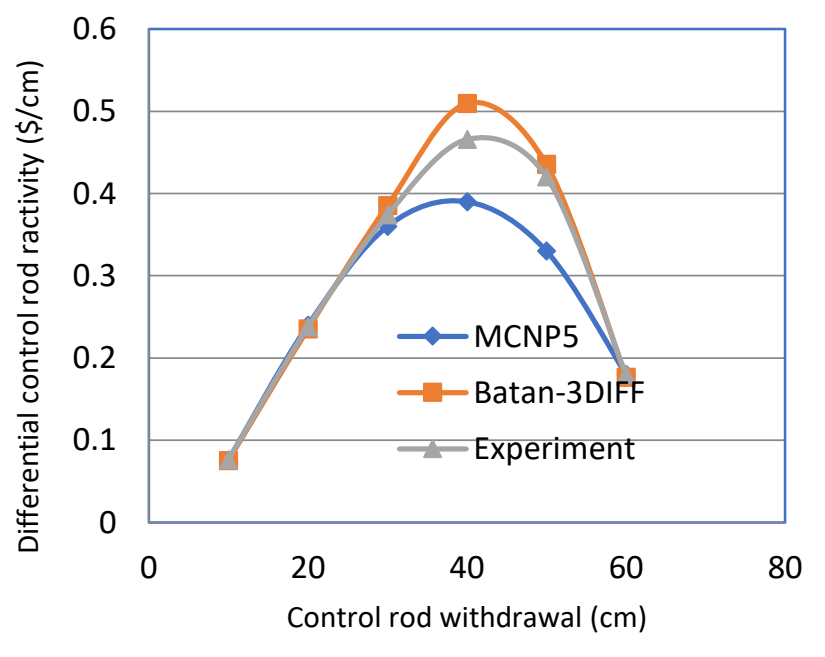

Figure 8. Differential control rod reactivity. 
Jurnal Iptek Nuklir Ganendra

Ganendra Journal of Nuclear Science and Technology

Vol. 24 No. 1, January - 2021: 11-20

Figure. 8 shows the differential control rod reactivity from measurement data, MCNP5, and Batan-3DIFF results. The slope of the graph is the amount of reactivity per unit height of the control rod withdrawal and the greatest reactivity lies in the center position of the control rod. Therefore, in this area, the greatest absorption of neutron flux, this result meets the reactor core design. If the slope of the curves for integral rod worth in Figure. 8 is plotted with the position of the control rod.

Table 4. Total control rod reactivity from calculation and measurement results.

\begin{tabular}{llll}
\hline Parameter & MCNP5 & Batan-3DIFF & Measurement \\
\hline Total control rod reactivity & $-(13.03 \pm 0.05)$ cents & -13.67 cents & $-(13.42 \pm 0.5)$ cents \\
& $-17.03 \$$ & $-17.87 \$$ & $-17.54 \$$ \\
$\begin{array}{l}\text { Calculation/Measurement } \\
\text { ratio }\end{array}$ & $3.0 \%$ & $1.9 \%$ & - \\
\hline
\end{tabular}

The result is a value for the rate of reactivity change of control rod worth as a function of control rod position. Differential control rod reactivity can be defined as a plot result from the slope of the integral curve to the height of the control rod. At the bottom of the core, where there are few neutrons; therefore, rod movement has little effect ( 0.1 $\$ / \mathrm{cm}$ ) and the change in rod worth per $\mathrm{cm}$ does not vary much. When the control rod is lifted close to a height of 20 $\mathrm{cm}$, the effect on reactivity is greater and the greatest change in differential reactivity of control rod is found in the center of the core. From the center of the core to the top, the rod worth per $\mathrm{cm}$ is the inverse of the rod worth per $\mathrm{cm}$ from the center to the bottom. Differential worth curves for all four groups cross-section are illustrated in Figure 8 for our calculations using deterministic and Monte Carlo results. Figure. 8 also includes the measurement result for RSGGAS working core.

The result of Batan-3DIFF for differential reactivity of control rod can be considered good enough to be utilized for reactor operation, although the code give a highest peak value and sharper differential curve shape. A comparison among those results for differential reactivity of RSG-GAS control rod illustrates our lower optimized (MCNP5) than the higher optimized results (Batan-3DIFF). The MCNP5 result is also given in the Figure. 8, which matches with our lower optimized method as a shape. A higher optimized result is much sharper than the optimized measurement results. It should be mentioned that all curves for all methods are calculated with the same conditions under which the measurement has been performed. The calculation result is validated by measurement data. The measurement method estimates the worth more accurately than WIMSD-5B/Batan-3DIFF and shows its capability to effectively and accurately calculate the reactor physics parameters.

The measuremets were compared to both calculation results of the curves from MCNP5 and Batan-3DIFF codes. A comparison between the measurement result and MCNP5 calculations shows a 3.0 \% difference. However, a comparison of the measurement result and Batan-3DIFF results show that the control rod reactivity worth curves exhibit a $1.9 \%$ difference which showed in Table 4 . The comparison results show that the integral and differential reactivity worth which results from measurements exhibit a better agreement with the Batan-3DIFF results; for that reason, that curve is currently used by the RSG-GAS operations. Control rod worth is the main concern to the ensure operational safety of the reactor. The maximum reactivity of the control rods which is obtained from the measurement and calculations exhibits a difference of about $10 \%$ in the worst case.

The present reactivity of the control rods decreases from the previously measured reactivity of the control rods and it will decrease continuously in the future because of its use and core burn-up. The total reactivity value of control rods from design result was $-14,2$ cents [10].

The obtained differential curves are not exactly symmetrical about the midpoint of the rod and integral curves are not purely S-shaped. This is due to the neutron flux distribution in the RSG-GAS working core. From the analysis 
of these results obtained in this research, it was concluded that the control rod worth is sufficient to shut down the reactor safely. These research results can be used as a reliable control rod worth of the working core of RSG-GAS for verification and validation and also for periodic safety review (PSR).

\section{CONCLUSION}

The calculation results of the differential and integral reactivity of control rod worth are good enough to be used in reactor operation, although the Batan-3DIFF calculation provides the highest peak value and the shape of the differential curve is sharper. The comparison between the measurement data, Batan-3DIFF, and MCNP5 calculation results show a good agreement. The maximum reactivity of the control rods which is obtained from the measurement and calculations exhibits a difference of about $3 \%$ in the worst case. It was concluded that the control rod worth is sufficient to shut-down the reactor safely. These research results can be used as a reliable control rod worth of the working core of RSG-GAS for verification and validation and also for periodic safety review (PSR).

\section{ACKNOWLEDGMENTS}

The authors wish to express special thanks to Head of BFTR Division for his fruitful discussions and also to Head of PTKRN-BATAN for his support and also thank you to the Management of PTKRN. This research was funded from the DIPA PTKRN-BATAN Year 2020.

\section{REFERENCES}

[1] Setiyanto and T. Surbakti. "Analysis of gamma heating at TRIGA mark reactor core Bandung using plate-type fuel," Jurnal Tri Dasa Mega., vol. 18, no.3, pp. 127-134, 2016.

[2] M. Rahgoshaya, O. N. Kalkhoran, "Calculation of control rod worth and temperature reactivity coefficient of fuel and coolant with burn-up changes for VVRS-2 MWth nuclear reactor." Journal of Nuclear Engineering and Design., vol. 256, pp. 322-331, 2013.

[3] T, Surbakti and T. M. Sembiring, "Neutronics analysis on mini test fuel in the RSG-GAS core," Jurnal Tri Dasa Mega., vol. 18, no.1, pp. 29-40, 2016.

[4] T. Surbakti and M. Imron, "Fuel burn-up calculation for RSG-GAS working core." Jurnal Penelitian Fisika dan Aplikasinya., vol. 7, no. 2, pp. 89-101, 2017.

[5] Rokhmadi dan T. Surbakti, "Effect of fuel density on reactivity coefficient parameter of the RRI core design," Jurnal Tri Dasa Mega., vol. 15, no. 2, pp. 77-89, 2013.

[6] L. Suparlina, "RSG-GAS core conversion management of high loaded silicide fuels,". Jurnal Tri Dasa Mega., vol. 15, no. 3, pp. 137-149, 2013.

[7] T. Surbakti dan Purwadi, "Reactivity characteristic of the RSG-GAS working core for 30 years operation," Jurnal Penelitian Fisika dan Aplikasinya., vol. 7, no. 1, pp. 13-26, 2017.

[8] T. Surbakti, S. Pinem, T. M. Sembiring, L. Suparlina, J. Susilo, "Neutronics conceptual design of the innovative research reactor core using uranium molybdenum fuel," Jurnal Tri Dasa Mega., vol. 3 no. 14, pp. 178-191, 2012.

[9] T. Surbakti, T. M. Sembiring, S. Pinem, "Analysis of silicide fuel density effect on the kinetic parameters of the RSG-GAS reactor core," Jurnal Penelitian Fisika dan Aplikasinya., vol. 3, no. 1, pp. 19-30, 2013.

[10] Batan. Safety Analysis Report of RSG-GAS rev 10.1, 2011.

[11] L. P. Hong, "Development of an In-core fuel management code for serching equilibrium core in 2-D reactor geometry (Batan-equil-2D)," Journal Atom Indonesia., vol. 23, no. 1, pp. 1-19, 1997. 
[12] S. Pinem, T. M. Sembiring, P. H. Liem. Neutronic and thermal-hydraulic safety analysis for the optimization the Uranium target in the RSG-GAS reactor. Journal of Atom Indonesia., vol. 42 no.3, pp. 123-128, 2016. DOI: dx.doi.org/10.17146/aij.2016.532.

[13] S. Pinem, T. M. Sembiring, T. Surbakti, G. R. Sunaryo, "Reactivity Coefficient Calculation for AP1000 Reactor Using the NODAL3 Code. Journal of Physics," Conference Series., vol, 962 no.1, 0120572018.

[14] S. Pinem, T. M. Sembiring, T. Surbakti, I. Kuntoro, "Neutronic Analysis on Irradiation of the Leu Electroplating Target in the RSG-GAS Reactor for Production of 99mo Radionuclide," GANENDRA Majalah IPTEK Nuklir,. vol. 21, no. 2, pp. 55-61, 2018.

[15] S. Pinem, T. Surbakti, T. M. Sembiring, "Core Design TRIGA2000 Bandung Using U3Si2Al Fuel Element MTR Type," Urania Jurnal Ilmiah Daur Bahan Bakar Nuklir., vol. 24, no. 2, pp. 93-103, 2018.

[16] P.H. Liem, T. Surbakti, and S. Donny, "Kinetics parameters evaluation on the first core of the RSG GAS (MPR-30) using continuous energy Monte Carlo method.". Progress in Nuclear Energy., vol. 109, pp. 196203, 2018.

[17] S. Pinem, P. H. Liem, T. M. Sembiring and T. Surbakti, "Fuel element burnup measurements for the equilibrium LEU silicide RSG GAS (MPR-30) core under a new fuel management strategy". Annals of Nuclear Energy., vol. 98, pp. 211-217, 2016.

[18] S. Pinem, T. M. Sembiring, T. Surbakti, "Core conversion design study of TRIGA Mark 2000 Bandung using MTR plate type fuel element," International Journal of Nuclear Energy Science and Technology. vol. 12, no. 3, pp. 222-238, 2018.

[19] T. Surbakti, Purwadi, "Analysis of Neutronic Safety Parameters of the RSG-GAS Research Reactor at Serpong," Jurnal Penelitian Fisika dan Aplikasinya., vol. 9,no. 1, pp. 78-91, 2019.

[20] T. Surbakti, S. Pinem, T. M. Sembiring, A. Hamzah, K. Nabeshima, "Calculation of Control Rods Reactivity Worth of RSG-GAS First Core Using Deterministic and Monte Carlo Methods.". Atom Indonesia., vol. 45, no. 2, pp. 69-79, 2019. 